Article

\title{
Exploring the Locus of Anthropos in Market Ecology: When the Homo Politicus Converses with the Homo Economicus
}

Willard Enrique R. Macaraan

\begin{abstract}
The dilemma of the anthropos confuses him as to the advantage of the market to his existence. The market anthropos is seen as homo economicus, a self-interested, utility-maximizing individual. This popular belief is critically analyzed as to its nuances insofar as the homo politicus of John Rawls is concerned. The life of the market anthropos seeks consensus towards societal cooperation and justice. Popularly held to be dissenting, this paper seeks to explore their possible convergence in the light of the nuances predicated by Adam Smith and Rawls. Ultimately, it is argued that the anthropos in either startum of politics or market is not differentiated but is one and the same, contextually apart but anthropologically integrated. The cooperative homo politicus can also be a cooperative homo econonomicus just as both can be selfishly motivated and utilitarianist.
\end{abstract}

Keywords: Rawls, Smith, political liberalism, economic liberalism

ny attempt at reconstructing "economic liberalism" cannot but
include the theory of "political liberalism,"1 understood as a school
of thought associated with the argument of "embracing a conception of justice that seeks consensus on a framework for regulating and mediating only the political." 2 The core idea talks about striving for a kind of "consensus through reduction" 3 amidst the context of conflicting and differentiated religious, philosophical and social norms and principles. This claim, however, is never new. Such "consensus through reduction" of

${ }^{1}$ The term political liberalism was actually first introduced by John Rawls in his 1987 article "The Idea of an Overlapping Consensus," in Oxford Journal of Legal Studies, 7:1 (1987), 125.

2 Shaun P. Young, "The Concept of Political Liberalism," in Political Liberalism: Variations on a Theme (USA: State University of New York Press, 2004), 3.

${ }^{3}$ Rainer Frost, "Foreword," in Ibid., ix.

(c) 2014 Willard Enrique R. Macaraan

http://www.kritike.org/journal/issue 14/macaraan june2014.pdf

ISSN 1908-7330

$(\mathrm{cc})$ BY-NC 
variants of conflicting narratives is already found in several historical discourses, even much older than liberalism itself. ${ }^{4}$ What is new, however, is Rawl's version of it - the "political" consensus that binds the members of a liberal political community together is not just devoid of religious meaning but is also no longer committed to a "comprehensive moral doctrine." ${ }^{5}$ It is a liberal project that is seen as a culmination of the history of countless attempts to establish political unity in ethical differences, anchored on common principles of justice to be "freestanding" 6 and binding in all relevant cases of conflict and to take priority over rival conceptions of the just or the good. A clear demarcation line is herein understood between justice and the good - the price liberalism has to pay for solving the great problem of e pluribus unum. Ingenuous as it is, Rawls at one point wondered why such breakthrough idea/theory has not been found earlier. ${ }^{7}$

It is clear for Rawls-his justice as fairness is political and not metaphysical. ${ }^{8}$ It is anchored on the context of society and that social unity is understood in the very concept of society as a system of cooperation between free and equal persons. The persons in Rawls' society, usually referred to as citizens, ${ }^{9}$ do not altogether affirm the same conception of good but publicly accept a political conception of justice to regulate the basic structure of society. The concept of justice is independent from and prior to the concept of goodness in the sense that its principles limit the conceptions of the good, which are permissible..$^{10}$ In the formation of a stable society, diverse groups/individuals set the minimum (and therefore basic) requirements for stability in the spirit of what is just (and fair) to all stakeholders; only after then is categorization of what is good (sentiments) allowed. The primacy of the criteria understood in terms of justice provides

4 "...There is Peter Abelard's attempt to identify a 'natural' core morality common to believers of different faiths, in Nicholas of Cusa's conception of una religio in rituum varietate or in Erasmus of Rotterdam's universal Christiana philosophia..." Ibid.

${ }^{5}$ It is defined as a 'moral ideal to govern all of life'. John Rawls, "Justice as Fairness: Political not Metaphysical," in Philosophy and Public Affairs, 14:3 (1985), 245.

${ }^{6}$ By 'freestanding,' it means independent and yet acceptable from the point of view of plurality of incompatible comprehensive doctrines. Frost, "Foreword," $x$.

7 See John Rawls, "Reply to Habermas," in Journal of Philosophy, 92:3 (1995), 133.

8 "Thus the aim of justice as fairness as a political conception is practical, and not metaphysical or epistemological. That is, it presents itself not as a conception of justice that is true, but one that can serve as a basis of informed and willing political agreement between citizens viewed as free and equal persons." Rawls, "Justice as Fairness: Political not Metaphysical," 230.

9 "Since Greek times, both in philosophy and law, the concept of the person has been understood as the concept of someone who can take part in, or who can play a role in, social life, and hence exercise and respect its various rights and duties. Thus we say that a person is someone who can be a citizen, that is, a fully cooperating member of society over a complete life." Ibid., 233.

${ }^{10} \mathrm{Ibid} ., 249$.

(c) 2014 Willard Enrique R. Macaraan

http://www.kritike.org/journal/issue 14/macaraan june2014.pdf

ISSN 1908-7330 
the basic foundation of stable society while the criteria set forth in terms of good are contingent upon its contribution to stability of society, henceforth, secondary.

\section{Rawlsian Justice as a Moral Concept}

While it is clearly explicit that Rawls' political concept of justice as fairness is in the context of superiority of justice over good, or what he termed as "priority of right," 11 he still maintains that his concept of justice is a "moral conception."

...Justice as fairness is a moral conception: it has conceptions of the person and society, and concepts of right and fairness, as well as principles of justice with their complement of the virtues through which those principles are embodied in human character and regulate political and social life. This conception of justice provides an account of the cooperative virtues suitable for a political doctrine in view of the conditions and requirements of a constitutional regime. ${ }^{12}$

Many after Rawls referred to such as the "paradox of political liberalism."13 The paradox is that the conception must not be a moral one. For Rawls, however, there is no contradiction as moral conception of justice as fairness merely refers to inclusion of the "conceptions of person and society, of right and fairness, as well as principles of justice with their complementary virtues through which those principles are embodied in human character and regulate political and social life." 14 The moral conception of Rawlsian justice does not reject values attached to moral as completely alien and therefore separated from the very concept of right/justice. This is the mistake of those who find the moral character of justice as an oxymoron of sort, due of course to their absolute categorization of moral and political as not only opposite but relatively hostile to one another. For Rawls, there are shades of gray. It was and has never been a

11 "Elsewhere I have called this relation between a conception of justice and conceptions of the good the priority of right (since the just falls under the right)." Ibid., 250.

${ }^{12} \mathrm{Ibid} ., 247$.

13 "... The Rawlsian theory fails to explain the normative character of this kind of moral conception, for it seems that the political conception can be acceptable in an overlapping consensus only if it is precisely not itself a moral conception but only becomes one in the eyes of the different comprehensive doctrines, being dependent upon their particular affirmation." Frost, "Foreword," xi.

${ }^{14}$ Rawls, "Justice as Fairness: Political not Metaphysical," 247.

(c) 2014 Willard Enrique R. Macaraan

http://www.kritike.org/journal/issue 14/macaraan june2014.pdf

ISSN 1908-7330

$(\mathrm{cc}) \mathrm{BY}-\mathrm{NC}$ 
black and white demarcation. It is more understood in a qualified and conditional sense-on the condition that such conception of justice provides an account of the cooperative virtues suitable for a political doctrine. ${ }^{15}$ This is more technically referred to by Rawls as "overlapping consensus." 16

The issue of poverty in the Philippine society serves as a fertile illustration. Various groups have already proposed solutions to address this social problem. There are those who start the poverty alleviation project from the standpoint of population control, best identified with the proponents of the Reproductive Health $(\mathrm{RH})$ bill. Some blame it on the inefficient government plagued by institutionalized practice of graft and corruption, best identified with civic groups like Bayan Muna, Anakpawis, among others. Still others see it as implications of an ineffective educational system producing more social liabilities than assets. Another position claims that it is due to lack of (quality) employment opportunities, caused by weak business climate for both domestic and foreign investments owing to poor security measures to maintain peace and order. Finally, one may contend the problem of poverty is deeply cultural and may even be religiously instigated or historically and culturally conditioned. ${ }^{17}$ All these are variants of comprehensive views that contain answers to the difficult and controversial issue of poverty in the Philippines. At some point of divergence, convergence is possible. At some point, people should be able to consent to their political arrangements, understood and accepted by each member of society, according to the dictates of his or her own reason. This is what is meant by the normative character of Rawls' overlapping consensus - diverse people at some point can agree on identifying principles to contribute to social stability. ${ }^{18}$ In the context of diversity, justice as fairness calls every stakeholder to a consensus that poverty should be alleviated as it is not fair for other members of society to suffer while the rest enjoy. In this sense, stability is achieved, somehow.

The proviso for a moral conception of Rawlsian justice is hereby deemed important in this discursive exploration of anthropos in economic liberalism. The basic assumption is that if political liberalism situates the

\footnotetext{
${ }^{15}$ Italics emphasized. Ibid.

16 "Briefly, Rawls argues that in spite of their [different comprehensive views] important differences, people who subscribe to diverse comprehensive views are able to agree in regard to a range of issues and principles bearing on society's basic institutions. Though people will support these principles for different reasons, with those of each person stemming from his or her own comprehensive view, the area of agreement throughout society will be sufficiently broad to contribute to the stability of liberal societies." George Klosko, "An Empirical Approach to Political Liberalism," in Political Liberalism: Variations on a Theme, 130.

${ }_{17}$ For a detailed reference on this, see Asian Development Bank, Poverty in the Philippines: Causes, Constraints, and Opportunities (Mandaluyong City: ADB, 2009), 39-52.

18 John Rawls, Political Liberalism (New York: Columbia University Press, 1993), 3-4.

(C) 2014 Willard Enrique R. Macaraan http://www.kritike.org/journal/issue 14/macaraan june2014.pdf

ISSN 1908-7330 
anthropos as an essential, if not primordial, agent in the formation of stable society, given of course the anthropos' societal situation of deep divisions between opposing and incommensurable conceptions of the good, then there is no reason to suspect that the homo politicus of Rawls, while fundamentally political, is capable of moral powers in the context of socially cooperative and free democratic society.

Justice as fairness starts from the idea that society is to be conceived as a fair system of cooperation and so it adopts a conception of the person to go with this idea. Here the focus shifts to the anthropos of political liberalism -its character, dynamics, and most importantly, its ethical/moral dimension-in the context of Rawls' diverse liberal societies. In this paper, the political anthropos is to be referred to as homo politicus.

\section{Semantic Nuances of Homo Politicus}

Before exploring the disposition of homo politicus, it is worth delving on some interesting yet puzzling discoveries of the term at least in the archaeological sense. First, while common impression holds that this concept of homo politicus is original to Rawls, it is not. It antedates even one of his early articles, "Justice as Fairness: Political not Metaphysical" in 1985. In the said article, Rawls mentions the term in discussion as something that has already been in the circle of scholarship: "There are, of course, many aspects of human nature that can be singled out as especially significant depending on our point of view. This is witnessed by such expressions as homo politicus, homo oeconomicus, homo faber, and the like."19 It therefore appears that the term has indeed already been relatively established.

Second, the semantic quandary is even bolstered by the discovery that homo politicus is generally credited by many scholars to Karine Nyborg ${ }^{20}$ and Bruce Carruthers, ${ }^{21}$ working along the lines of ecological economics and sociology, respectively. What is, however, confusing here is that their "original" use of homo politicus appeared in their articles printed in the year 2000 and 1994, respectively. If Rawls mentioned this term in his 1985 article, why would the credit be given to them whose assumed original use was years after the former? The presumption is that the term has already been

${ }^{19}$ Rawls, “Justice as Fairness: Political not Metaphysical," 232.

${ }^{20}$ Karine Nyborg, "Homo Economicus and Homo Politicus: Interpretation and Aggregation of Environmental Values," in Journal of Economic Behavior and Organization, 42:3 (2000), 305-22.

${ }^{21}$ Bruce G. Carruthers, "Homo Economicus and Homo Politicus: Non-Economic Rationality in the Early $18^{\text {th }}$ Century London Stock Market," in Acta Sociologica, 37:2 (1994), 16594.

(c) 2014 Willard Enrique R. Macaraan http://www.kritike.org/journal/issue 14/macaraan june2014.pdf ISSN 1908-7330 
there all along but has never been fully and scholarly defined until Nyborg and Carruthers did.

Third, the concept of homo politicus, at least in the articles of both Nyborg and Carruthers, was often utilized as a conversant of homo economicus although understood in different capacities. For Nyborg, the homo politicus is offered as antithesis (protagonist) to homo economicus (antagonist).22 For Carruthers, meanwhile, there is convergence and oneness of existence for both homo economicus and homo politicus. "Economic action in this market was embedded in politics and ethnicity, and homo economicus was also homo politicus....Homo economicus and homo politicus were in the market together." 23

Fourth, it may be argued that the use of homo politicus in this discourse to refer to the anthropos may be completely arbitrary and, therefore, may not correspond to the "original" spirit of such term, taken of course in the sense as used by both Nyborg and Carruthers. This is, however, to be refuted as both of them understood the term in the context of what Rawls considered as the function and locus of his political anthroposas an individual in pursuit of "political justice" in the context of stable society. "The homo politicus is based on ethical considerations essentially characterized by its 'striving for political justice'. It recognizes this striving as an essential trait of its existence as a being capable of reason...." 24

\section{Homo Politicus as a Moral Anthropos: The Two Moral Powers}

There is indeed justification for the decision to articulate the political anthropos of Rawls as homo politicus. After settling what may be considered as nuances of meaning and semantics, it is important now to define the identity of this homo politicus in Rawlsian world with particular emphasis on its moral capacity.

The starting point of Rawls' thesis is the recognition of the diversity present in any liberal society, characterized as "unbridgeable" and thereby inherent. ${ }^{25}$ The permanent stamp of such diversity is drawn from an acknowledgment of fundamental disagreements among people emphasizing different aspects of questions and employing different

${ }^{22}$ See Malte Faber et al., "Homo Oeconomicus and Homo Politicus in Ecological Economics," in Ecological Economics, 40 (2002), 326. See also Robert A. Young, Determining the Economic Value of Water: Concepts and Methods (USA: Resources for the Future Press, 2005), 147.

${ }^{23}$ Carruthers, "Homo Economicus and Homo Politicus: Non-Economic Rationality in the Early $18^{\text {th }}$ Century London Stock Market," 166.

${ }^{24}$ Christian Becker, "The Human Actor in Ecological Economics: Philosophical Approach and Research Perspectives," in Ecological Economics, 60 (2006), 19.

${ }^{25}$ Klosko, "An Empirical Approach to Political Liberalism," 130.

(c) 2014 Willard Enrique R. Macaraan http://www.kritike.org/journal/issue 14/macaraan june2014.pdf

ISSN 1908-7330 
methods of investigation, resulting in various and irreconcilable answers. ${ }^{26}$ With objective towards a stable society characterized by social unity, without of course denying its recognized diversity, Rawls sees the need for a kind of consensus that may overlap among the "fragmented" differences. ${ }^{27}$ With consensus, it necessitates the presence of a fully cooperating member of society. Henceforth, the homo politicus for Rawls is briefly defined as "full participants in a fair system of social cooperation, with capacity for two moral powers connected with the elements of social cooperation: a capacity for a sense of justice and a capacity for a conception of the good." 28 Here these two morals as capacities for a full cooperating homo politicus need further exposition.

For Rawls, the sense of justice is the capacity to understand, apply, and act in terms of a generally approved conception of justice that characterizes the fair terms of social cooperation. ${ }^{29}$ It is simply to choose the course of action that is aligned with the social contract agreed upon by a general account of all homines politici. In this case, it may refer to the law of the land implemented by the state in minimalist sense that is good enough for a just and fair exercise for social cooperation. The traffic law and regulations implemented in Metro Manila require all in the area to cooperate so as to maintain stability in society. That is a minimum requirement understood in the conception of political justice. On the other hand, Rawls' conception of the good allows the homo politicus "to form, revise, and rationally pursue one's rational advantage, or good." ${ }^{30}$ This concerns the creative capacity of the homo politicus, understood not in egoistic term but on the conception of what is valuable in human lifetranscending the law beyond its letter and realizing specific ends for their own sake as well as of attachments to other persons, groups, and associations. These attachments give rise to flourishing of the persons and associations as objects of the sentiments of affections and devotions. While to obey the traffic law maintains stability in society, this conception of the good allows some forms of modification from the rigor of the law, not for the sake of narrow interest but still for the promotion of social stability. Take the case, for example, of approved exemptions in traffic laws like

26 "Rawls calls this fact of human reason the 'burdens of judgment,' and he argues that a diversity of doctrines is a permanent feature of liberal public culture, not an accident of history, destined to pass away." Ibid.

27 "Justice as fairness seeks to identify the kernel of an overlapping consensus, that is the shared intuitive ideas which when worked up into a political conception of justice turn out to be sufficient to underwrite a just constitutional regime." Rawls, "Justice as Fairness: Political not Metaphysical," 246.

${ }^{28}$ Ibid., 233.

${ }^{29} \mathrm{Ibid}$.

${ }^{30} \mathrm{Ibid}$.

(c) 2014 Willard Enrique R. Macaraan

http://www.kritike.org/journal/issue 14/macaraan june2014.pdf

ISSN 1908-7330

(cc) BY-NC 
emergency privilege of priority pass to ambulances, fire trucks, and police cars, among others. Such case of tolerance does not destroy the conception of justice as it even promotes dynamism in an already stable society-if and only if such exemption is still warranted by the consensus of all.

\section{The Homo Politicus as an Anthropos for Freedom and Equality}

Aside from the two moral powers for the conception of justice and good, it is also assumed that the conception of the political anthropos necessitates as basic intuitive idea its being free and equal. This is part of Rawls' proposed solution to both the liberal critique of aristocracy and the socialist critique of liberal constitutional democracy. There is, however, a need to clarify still the nature of the political anthropos as free in order to transcend the metaphysical ambiguity that surrounds the concept of freedom in the classical times. For Rawls, the homo politicus views himself as free in three respects: 1) having moral power to conceive the good, 2) capacitated as a self-originating source of valid claims, and 3) capable of being responsible for his actions. ${ }^{31}$ From this, it is evident that although the homo politicus is understood initially by Rawls as a mere member/unit of the desired stable and democratic society, his thesis on justice as fairness as the core of such overlapping consensus legitimates the primordial status and role of his political anthropos in the formation and maintenance of social unity and cooperation. Hence, the homo politicus is not only a unit of society but a self-determining person capable of not only the conception of justice but also of the good. The homo politicus is primarily a person understood with moral powers to initiate actions based on personal choices, however, understood not in mere narrow self-interest but still for what is of value to the life of the political anthropos. Briefly assumed thereon, the homo politicus is a person who is capable of extending beyond the rigor by the capacity for revision and formation of relationships, sentiments, loyalties-sufficient environment for a feasible praxis of compassion. Indeed, the homo politicus can be compassionate.

\section{Economic Anthropos: The Case of Homo Economicus}

The focus now shifts to the economic anthropos herein to be referred as homo economicus. Just as homo politicus in this discussion has been found to include some sort of confusion in its archeological sense, the concept of homo economicus is no different. ${ }^{32}$ It has been generally associated with Adam

${ }^{31}$ Ibid., 240-244.

32 Edward O'Boyle attempts to trace the origin, as any archeologist does, by whose earliest hand this expression came into use. Such attempt is not easy. In the end, he is led to 
Smith, not because the exact expression is found in any of his great works, but because it is mainly due to the idea and thought that has since defined the character of homo economicus as such-self-interested and utilitymaximizing individual who cares not about anything else but himself $-\mathrm{a}$ character of the economic anthropos that is inscribed in Smith's Wealth of Nations, ${ }^{33}$ considered as his magnum opus.

It is not from the benevolence of the butcher, the brewer or the baker, that we expect our dinner, but from their regard to their own interest. We address ourselves not to their humanity but to their self-love, and never talk to them of our own necessities but of their advantages. ${ }^{34}$

The popular consensus then reveals an egoistic anthropos ${ }^{35}-$ someone who is judged to be concerned with nothing about the concept of "helping" for the cause of others except only if by doing so, it would reap him/her increased profit and reward. Much criticized in the "shortcomings" of homo economicus, it is believed to be a case of oversimplification as there are findings that reveal a social sense (altruism, sympathy) that can be deemed congruent if not inherent to the person of the homo economicus. ${ }^{36}$

Herein rests the central issues that must be addressed for the concept of homo economicus. What nuances are inherent in the nature of homo economicus as a self-interested anthropos? If homo economicus carries with it a popular connotation of a self-interested, calculating and therefore egoistic anthropos, what degree of confluence, if ever feasible, can such individual exercise in his meeting with the homo politicus, understood as a more

assume that the full expression of the term originated from German-language economics literature but still without finality due to his unfamiliarity with the German language. See Edward J. O'Boyle, "The Origins of Homo Economicus: A Note," Unpublished paper (Louisiana: Mayo Research Institute, 2008).

${ }^{33}$ Published in 1776, it bears the original title An Inquiry into the Nature and Causes of the Wealth of Nations. Usually abbreviated as The Wealth of Nations, it is considered the first modern work of economics. It earned him an enormous reputation and became one of the most influential works on economics ever published. Since then, he was considered the father of modern economics.

${ }^{34}$ Adam Smith, An Inquiry into the Nature and Causes of the Wealth of Nations, Vol. 1 (The Pennsylvania State University: A Penn State Electronic Classics Series Publication, 2005), 72-3.

${ }^{35}$ For J. Gray, the homo economicus is an opportunistic and calculating individual who does not abide by fixed rules. For P. Söderbaum and K. Nyborg, it is a consumer maximizing utility or an individual who is pursuing only short-sighted interests. See Faber et al. "Homo Oeconomicus and Homo Politicus in Ecological Economics," 324.

${ }^{36} \mathrm{Ibid}$.

(c) 2014 Willard Enrique R. Macaraan

http://www.kritike.org/journal/issue 14/macaraan june2014.pdf

ISSN 1908-7330

(cc) BY-NC 
socially-driven individual? To what degree, if ever possible, can the homo economicus be contributive to the project of praxis of compassion, at least by the conception of his natural capacity as a self-interested anthropos? The aim, therefore, of this investigation is to forward the locus of anthropos in a presumably objectified and reified existence of the homines economici in market society. Henceforth, the three foci by which this particular subject would be discussed: 1) on the connotations associated with "self-interest" as basic motivation of homo economicus, 2) on the issue of the possible convergence of the homo politicus and the homo economicus, and 3) on the legitimacy of the case of homo economicus in forwarding the thrust of a praxis of compassion.

It has to be noted at the onset that a considerable amount of literature that has discussed this coming together of homo politicus and homo economicus is usually in the area of ecological economics with a more social thrust towards sustainable ecology (nature) in the face of market dynamics, thus, the entry of such human models as homo sustinens ${ }^{37}$ and homo ecologicus. ${ }^{38}$ It is argued that a self-interested model of a person in the market, the homo economicus, is not appropriate insofar as sustainable development is concerned. There is perceived egoism inherent in the dynamics of market anthropos whose intention and behavior serves only himself and himself alone. If ever, to some extent, there is a positive contribution to the welfare of the ecology, it is mainly accidental and perhaps an unintended consequence only. ${ }^{39}$ So strong is their opposition to homo economicus that there is a need to revisit its self-interest motivation.

\section{Homo Economicus as Self-Interested Anthropos: Narrow and Rightly-Understood}

Adam Smith's vision of society is "justice and not self-interest." 40 Smith's individual, while driven by self-interest, is also capable of sympathy as an ethical foundation for a rational behavior in market. ${ }^{41}$ It is a mistake, therefore, a case of oversimplification, to refer to homo economicus as

\footnotetext{
37 Ibid., 332.

38 Becker, "The Human Actor in Ecological Economics: Philosophical Approach and Research Perspectives," 20.

${ }^{39}$ See C. Daniel Batson, "Empathy-Induced Altruism: Friend or Foe of the Common Good?," in For the Greater Good of All: Perspectives on Individualism, Society and Leadership, Donelson R. Forsyth \& Crystal L. Hoyt, eds. (New York: Palgrave Macmillan, 2011), 29.

${ }^{40}$ See Lawrence R. Cima and Thomas L. Schubeck, "Self-interest, Love and Economic Justice: A Dialogue between Economic Liberalism and Catholic Social Teaching," in Journal of Business Ethics, 30 (2001), 228.

${ }^{41}$ James D. Marshall, "Varieties of Neo-Liberalism: A Foucaultian Perspective," in Educational Philosophy and Theory, 33:3-4 (2001), 295.
} 
reducibly egoistic as many commentators on Smith's writings had led people to think. There are at least two senses by which self-interest is to be discerned insofar as Smith is concerned: self-interest as selfishness and interest of a self. The former is egoism while the latter may be othercentered and generous - a view that is also shared by Milton Friedman. ${ }^{42}$ It can be argued, therefore, that while homo economicus may be principally motivated by self-interest as such, there are nuances that must be addressed insofar as its pure intention is concerned. It is assumed that while the homo economicus acts always with self-interest, such behavior may either be classified as either "narrow" self-interest or "enlightened" self-interest. Such variants need, therefore, to be explicated.

Self-interest is an anthropological presupposition common to many economic models. Mainstream economics today presumes that every action taken by the individual is self-interested in the sense that it pursues some interest of the self. Thus, both De La Salle University President Bro. Jun Erguiza, FSC and a thief along Taft Avenue in Manila are described as pursuing their self-interest, even though the former provides a conducive environment for quality education among LaSallian students while the latter preys upon them. Self-interest is here understood as the interest of the self, which could include narrowly selfish or broadly altruistic goals held by the actor. The phrase "narrow self-interest" refers to actions in which the self (perhaps including a few loved ones near the self) is the intended beneficiary of the action while a rather extended sense of self-interest is usually employed in terms, such as "enlightened self-interest," or what Alexis de Tocqueville more than a century ago called self-interest "rightly understood." 43

Whether narrow or enlightened, still, the value assumption is that every behavior is self-interested-“...that all human action is directed toward self-interest. The understanding of what is in the self's interest may change, the understanding of how the self is defined may change, but the assumption that all action is directed toward self-interest remains." 44 But as to how a self-interested action, given its inherent character in all actions thereof, assumes an "enlightened" or "rightly understood" dimension remains a question. Batson suggests a number of categories by which the self-interest may be enlightened: 1) consideration of long-term

42 "The CEL [classical economic liberalism] concern is that self-interest as othercentered should not be imposed on the individual by the state. Its concern is not to defend selfishness. The issue for Smith and Friedman is how to preserve freedom, not how to protect greed." Emphasis added. Cima and Schubeck, "Self-interest, Love and Economic Justice: A Dialogue between Economic Liberalism and Catholic Social Teaching," 216.

${ }^{43}$ Daniel K. Finn, The Moral Ecology of Markets: Assessing Claims about Markets and Justice (New York: Cambridge University Press, 2006), 58.

${ }^{44}$ Batson, "Empathy-Induced Altruism: Friend or Foe of the Common Good?," 33.

(c) 2014 Willard Enrique R. Macaraan

http://www.kritike.org/journal/issue 14/macaraan june2014.pdf

ISSN 1908-7330

(cc) BY-NC 
consequences, 2) attention to "side payments," 45 and 3) self-categorization theory. ${ }^{46}$

The first category speaks of the willingness of the homo economicus to act in a way that promotes the common good for a short term as an instrumental means to maximize self-benefit in the long term. Hence, a certain junior professor who is on probationary status for job permanency may opt to sacrifice his time to enjoy and have fun with family and friends by focusing instead on finishing his dissertation as a requirement for job permanency on top of fulfilling his department assignments and extracurricular projects-all these in order to maximize the privileges and benefits he may receive as a permanent faculty member in the long run.

The second category deals with the concept of side payment that occurs when the homo economicus avoids decisions and actions at the expense of the group, especially if others do not do likewise. This he also does to spare himself from criticism, accusations, guilt and shame, consequently avoiding punishment while anticipating social and selfrewards. A classic articulation of the often-quoted, "If you can't beat the group, join them" is evident in the case of a newly-hired professor who defers his own values and principles against the backdrop of a deeplyembedded cultural practice and artifact in his workplace in order to gain acceptance and eschew termination.

The third category is on the self-categorization theory that rest on the idea that the self can be defined not only at the personal level but also at the group level. This is different from the second category (side payments) that speaks about acting for the common good, where the self whose benefit is maximized is still the personal self, where common good is seen as unintended consequence of personal self-interest. Self-categorization theory does not challenge the assumption that one always acts to maximize selfbenefit; it only endorses the group identity more than the self. It involves suppression of differentiation between the self and other group members as individuals. ${ }^{47}$

What happens is the individual performs for the group primarily because he understands himself as a member of the group, more than anything else. This, for him though, is rewarding and thus is still selfinterested in some sense. It is "not me or thee but we." 48 Citing Republic Act

45 "Side payments include nontangible self-benefits of acting for the common good, self-benefits such as social and self-approval (e.g., admiration of others; personal pride at a good deed done) and avoidance of social and self-punishments (e.g., censure for violation of norms of fairness of reciprocity; pangs of conscience)." Ibid., 31-32.

${ }^{46}$ Detailed discussion is found thereafter. Ibid., 31-33.

${ }^{47}$ See J.C. Turner, Rediscovering the Social Group: A Self-Categorization Theory (London: Basil Blackwell, 1987), 65.

${ }^{48}$ Ibid., 83.

(c) 2014 Willard Enrique R. Macaraan

http://www.kritike.org/journal/issue 14/macaraan june2014.pdf

ISSN 1908-7330 
9335, otherwise known as "Attrition Act of 2005,"49 the members (officials and employees) of both the Bureau of Internal Revenue (BIR) and Bureau of Customs (BOC) are expected to contribute to the agencies' mandate of optimizing the revenue collection for a certain fiscal year. Known for its corrupt procedures and dishonest individuals, the self-categorization theory enjoins every individual to think and act as one unit (group), henceforth, maximizing the group benefit as is or more than the self. It is not that the BIR or BOC personnel would not get anything in return for personal selfinterest; it is merely that the agency takes precedence over personal gains while still being very much motivated by self-interest. In the end, if the target allocation is met, a certain percentage of any excess thereof is given to the bureaus' fund as mandated in the said legal provision-understood to satisfy the personal self-interested benefits of each member.

It is, therefore, deduced that from these three manifestations of "enlightened" self-interest, the normative character of self-interest rests not on its abstract definition alone but on its phenomenological manifestation in context, that is, it is overly simplistic and perhaps inconclusive to categorize both the actions of Bro. Erguiza and the thief as self-interested without critically identifying its world empirically. The moral dimension, therefore, of a self-interested act, practiced in economics by the homo economicus, should be seen as always in context. ${ }^{50}$

There is the dimension of "other" in homo economicus. Briefly, the economic anthropos is capable of looking after the other while still being selfinterested. At least on that regard, there is readiness for a more othercentered behavior - a presumed precursor for a praxis of compassion. Hence, the homo economicus can be compassionate.

\section{The Homo Politicus and Homo Economicus: Converging in Context}

For the second issue on the possible convergence of the homo politicus and the homo economicus, it is argued that after an explication of the nuances of self-interest as motivational principle of homo economicus and the previous categorization of homo politicus as a more socially-directed anthropos, there is a point of convergence, a meeting point or a confluence

49 "A Philippine state policy to optimize the revenue-generation capability of Bureau of Internal Revenue (BIR) and Bureau of Customs (BOC) by providing a system of rewards and sanctions through the creation of the Rewards and Incentives Fund and a Revenue Performance Evaluation Board in the above agencies for the purpose of encouraging their officials and employees to exceed their revenue targets." See complete document in <www. senate.gov.ph/republic_acts/ra9335.pdf>. Accessed (5 February 2012).

50 See Finn, The Moral Ecology of Markets: Assessing Claims about Markets and Justice, 148.

(c) 2014 Willard Enrique R. Macaraan

http://www.kritike.org/journal/issue 14/macaraan june2014.pdf

ISSN 1908-7330

(cc) BY-NC 
between these two anthropoi models. They are, after all, neither essentially differentiated nor hostile entities as misconceived by Nyborg and her companions in ecological economics. It is clearly assumed, at least in this paper, that these two anthropoi are not two existential individuals in actual history. They are indeed mere manifestations, essential representations of the roles and functions inherent in any human person in a certain contextmarket for the homo economicus and political society for the homo politicus. It is the one and same individual that may be simultaneously or separately manifesting and representing certain functions and roles posed therein by the context(s) - market and politics.

The point of mutual encounter is the ecology of both the homo economicus and the homo politicus. Not that they have one and the same ecology, although they do at times; it is rather on how the interaction of anthropos and context defines both the person and the structure. While the main motive of homo economicus is profit (self-interest) and homo politicus, generally approved consensus for stable society (justice as fairness), the inclination to consider the context (structure, others, common good) is an interesting space for meeting together. Accordingly, the homo economicus enjoys the profit that is due to him in terms of justice as fairness while still being open to formulate conception of the good through acts of donation and other forms of altruism in the context of "enlightened self-interest." Similarly, the homo politicus is satisfied with the stability of society through mutually consenting individuals while providing platforms for "selfinterested" homo economicus to forward their activities without undermining the agreed upon minimum requirements and conditions for the preservation of stable society despite differences and autonomy.

\section{Homo Economicus: A Legitimate Agent for Praxis of Compassion}

The third issue dwells on the legitimacy of the case of homo economicus in forwarding the thrust of a praxis of compassion. Based on above analysis, it is henceforth assumed that as manifestations of one and the same historical person, homo economicus and homo politicus are efficient models of anthropos towards justification of a world of cooperative individuals, seen in both its economic and political senses. The primordial discovery of this convergence between the economic and political anthropoi is the social readiness to acknowledge the presence of the other as a kind of extended self, where the enjoyment of any privilege is similar, or at least commensurate to one and all, taken individually as members of the same anthropological world. No matter what degree of self-interest may motivate the homo economicus, the consensus that is built and agreed upon by the society of homines politici shields and prevents abuses to take place for the

(c) 2014 Willard Enrique R. Macaraan

http://www.kritike.org/journal/issue 14/macaraan june2014.pdf

ISSN 1908-7330 
benefit of one, at the expense of the other. The world of homines economici may not sustain, as it is not inherent, equality among free individuals; the phenomenological presence, however, of abused individuals legitimates and justifies the primary thrust of this paper - a praxis of compassion in the context of market world. Transcending the world of free and equal homines politici, the world created and sustained by unequal homines economici necessitates a framework of altruism, generosity, and sympathy among others. The eventual differences and inequality in status, resource allocation, wealth distribution, and property ownership, among others, generated by the conditions inherent in naturally self-interested pursuit of hominess economici in any given market situation paves way for a social divide between the haves and have-nots. While construed as problematic, such inevitable outcome is thus argued as a suitable condition for the exercise of compassion by and among self-interested hominess economici, whose task for altruism and other-directed actions is not only feasible, but is also inherently natural, understood in terms of the "enlightened self-interest" dynamics. This is feasible by the nature and dynamics of economic anthropos as capable of transcending narrow (selfish) self-interests for the sake of others and the group at large. The enlightened self-interest suffices the framework to legitimize the claim for a praxis of compassion.

Smith's concept of the "invisible hand" provides a theoretical commonplace for the possible consensus or dialogue between the political anthropos and the economic anthropos. Defined as that "self-regulating nature of the marketplace,"51 it is a metaphor that serves to justify that the selfinterested, cost-benefiting and utility-maximizing homo economicus may actually contribute to the creation and sustenance of a stable market (society), something that the homo politicus would be happy about, even though there is no benevolent intention in the former's egoistic ambitions. There is something at work in a universal sense that orders all these various individual interests, no matter how differently articulated and realized, to contribute and to some extent arrange the exigencies of society towards stability.

He [Man] intends only his own security; and by directing that industry in such a manner as its produce may be of the greatest value, he intends only his own gain, and he is in this, as in many other cases, led by an invisible hand to promote an end which was no part of his intention. Nor is it always the worse for the society

51 Arthur Sullivan and Steven Sheffrin, Economics: Principles in Action (New Jersey: Pearson Prentice Hall, 2003), 32.

(c) 2014 Willard Enrique R. Macaraan http://www.kritike.org/journal/issue 14/macaraan june2014.pdf ISSN 1908-7330

$(\mathrm{cc}) \mathrm{BY}-\mathrm{NC}$ 
that it was no part of it. By pursuing his own interest he frequently promotes that of society more effectually than when he really intends to promote it. ${ }^{52}$

Its inherent autonomous character, aside of course from its "invisibility," is such that "no individualist capitalist, in theory, is in a position to influence the "invisible hand" to the detriment of his competitors." 53 If the "invisible hand" dynamics are assumed to allow provision of stable society - the same end by which the homo politicus operates-there is still much to be argued in terms of the degree of intentionality and initiative present between the two anthropoi. It is clearly evident that the conception of the stable society in political liberalism is achieved by fully-consenting citizens through their concept of "overlapping consensus." On the contrary, the operative character of the "invisible hand" does not necessitate and depend on any willful and intentional course of action for the society at large. Its dynamics relies on the self-interested actions and decisions of the homines economici, wholly unrelated, definitely unplanned, but adequate towards ordering and harmonizing these strewn personal interests for a stable market society.

The processes and dynamics of attaining the ordering of stable society may be different between the two anthropoi taken in each world context, yet mutual dialogue is pertinent inasmuch as both have intentional direction towards communal goal. With this finding, it can be argued that the anthropos of market, while naturally self-interested, is capable of not only an other-directed action but also a communal participation and possibly a compassionate-oriented praxis amidst the market dynamics.

Theology and Religious Education Department,
De La Salle University-Manila, Philippines

\section{References}

Batson, C. Daniel, "Empathy-Induced Altruism: Friend or Foe of the Common Good?" in For the Greater Good of All: Perspectives on Individualism, Society and Leadership, ed. by Donelson R. Forsyth \& Crystal L. Hoyt (New York: Palgrave Macmillan, 2011).

Becker, Christian, "The Human Actor in Ecological Economics: Philosophical Approach and Research Perspectives," in Ecological Economics, 60 (2006), 17-23.

52 Smith, An Inquiry into the Nature and Causes of the Wealth of Nations, Vol. 1, 366.

${ }^{53}$ Frederic F. Clairmont, The Rise and Fall of Economic Liberalism: The Making of Economic Gulag (Penang Malaysia: Southbound, 1996), 3.

(c) 2014 Willard Enrique R. Macaraan http://www.kritike.org/journal/issue 14/macaraan june2014.pdf

ISSN 1908-7330 


\section{EXPLORING THE LOCUS OF ANTHROPOS}

Cima, Lawrence R. and Schubeck, Thomas L., "Self-interest, Love and Economic Justice: A Dialogue between Economic Liberalism and Catholic Social Teaching," in Journal of Business Ethics, 30 (2001), 213-31.

Clairmont, Frederic F., The Rise and Fall of Economic Liberalism: The Making of Economic Gulag (Penang Malaysia: Southbound, 1996).

Faber, Malte et al., "Homo Oeconomicus and Homo Politicus in Ecological Economics," in Ecological Economics, 40 (2002), 323-33.

Finn, Daniel K., The Moral Ecology of Markets: Assessing Claims about Markets and Justice (New York: Cambridge University Press, 2006).

Frost, Rainer. "Foreword," nn Political Liberalism: Variations on a Theme, ed. by Shaun P. Young (USA: State University of New York Press, 2004).

Klosko, George, "An Empirical Approach to Political Liberalism," in Political Liberalism: Variations on a Theme, ed. by Shaun P. Young (USA: State University of New York Press, 2004).

Marshall, James D., "Varieties of Neo-Liberalism: A Foucaultian Perspective," in Educational Philosophy and Theory, 33:3-4 (2001), 293304.

O'Boyle, Edward J., "The Origins of Homo Economicus: A Note," Unpublished paper (Louisiana: Mayo Research Institute, 2008).

Rawls, John, "Justice as Fairness: Political not Metaphysical," in Philosophy and Public Affairs, 14:3 (1985), 223-251.

“ "Reply to Habermas," in Journal of Philosophy, 92:3 (1995), 13280.

"The Idea of an Overlapping Consensus," in Oxford Journal of Legal Studies, 7:1 (1987), 1-25.

Smith, Adam, An Inquiry into the Nature and Causes of the Wealth of Nations (The Pennsylvania State University: A Penn State Electronic Classics Series Publication, 2005).

Sullivan, Arthur and Sheffrin, Steven, Economics: Principles in Action (New Jersey: Pearson Prentice Hall, 2003).

Turner, J.C., Rediscovering the Social Group: A Self-Categorization Theory (London: Basil Blackwell, 1987).

Young, Shaun P., "The Concept of Political Liberalism," in Political Liberalism: Variations on a Theme, ed. by Shaun P. Young (USA: State University of New York Press, 2004).

(c) 2014 Willard Enrique R. Macaraan

http://www.kritike.org/journal/issue 14/macaraan june2014.pdf

ISSN 1908-7330 